\title{
Measuring Service Quality In Higher Education: A South African Case Study
}

Paul Green, Durban University of Technology, South Africa

\begin{abstract}
The goal of this paper is to report on the SERVQUAL gap which causes unsuccessful service delivery at a University of Technology in South Africa. Using a quantitative research design, the study adopts a SERVQUAL model adapted to a tertiary environment containing five dimensions of service quality (tangibles, responsiveness, empathy, assurance, and reliability). A convenience sampling technique was applied, the data were collected from 280 respondents at the Durban University of Technology (DUT), and the results and discussion are presented. The findings reveal that, on average, customers had high expectations in tangibles, reliability, and assurance dimensions and their highest perceptions were found in the assurance dimension. This study will benefit management of higher education institutions in identifying cost-effective ways of reducing service quality gaps.
\end{abstract}

Keywords: Service Quality; Tertiary Institutions; SERVQUAL; Customer Satisfaction; South Africa

\section{INTRODUCTION}

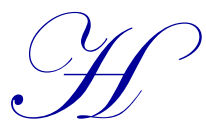

igher education institutions across the world have experienced the introduction of processes for quality assurance. The increasing competition among higher education institutions to attract highly qualified students toward achieving high academic profiles is forcing them to pay more attention to service quality issues. This makes it prudent to examine whether the quality process has produced the enhancement of core outputs.

This study measures expectations and perceptions of students and staff to determine their satisfaction of service quality provided at Durban University of Technology in South Africa. The subject of service quality measurement in higher education has recently attracted the attention of many researchers (Koni, et al., 2013; Sultan \& Wong, 2012; Jain, Sinha, \& Sahney, 2011; Lee, 2010; Abu Hasan et al., 2008; Pereda et al., 2007; Peng \& Samah, 2006; Petruzzellis et al., 2006). The institution's process and outcome affect students and staff judgment of service quality provided by the institution. The process involves how students and staff, as major service customers, are treated during the service interaction, and outcome is the actual result being experienced by the customers (Cuthbert, 1996). On a daily basis, students and staff will interact with the institution and experience varying degrees of services. Students' perceptions of the higher education experience have become increasingly important as institutions of higher education have attempted to become more student-centric (Khodayari \& Khodayari, 2011; Mahadzirah \& Wan, 2003).

Now this study, adopting a quantitative paradigm, investigates the quality of service delivered by identifying the difference between customer expectations of service and perceived service at two of the campuses of the Durban University of Technology (DUT), viz Riverside and Indumiso Campuses. It is equally important for DUT and other universities to identify whether the institution is meeting customer expectations in the higher education sector. The uniqueness of this study is its relation to universities of technology, which is relatively new in South Africa.

\section{LITERATURE REVIEW}

The concept of service can be defined as an intangible product that cannot be owned or stored, but it comes to an existence at the time and place it is delivered for consumption. Service quality is the extent to which a service 
meets or exceeds the expectations of customers (Jain, Sinha, \& De, 2010; Zeithaml, et al., 2006; Nitecki \& Hernon, 2000; Cronin \& Taylor, 1992; Boltan \& Drew, 1991; Lewis \& Mitchell, 1990; Parasuraman, 2004). The notion of difference is the degree and direction of discrepancy or gap between customer expectations and perceptions of a service (Parasuraman et al., 1985). The measurement of service quality has been illustrated along a continuum ranging from ideal quality to totally unacceptable quality with some point along the continuum representing satisfactory quality. The position of customer perceptions of service quality on the continuum depends on the nature of discrepancy between the expected service and the service perceived by the customer. On one hand, if expectations are greater than perceptions, the perceived service quality is less than being satisfactory and customer dissatisfaction is said to occur. On the other hand, if expectations are less than perceptions, perceived service quality is said to be satisfactory and will tend toward ideal quality with increased positive discrepancy between expected and perceived service quality.

Grönroos (2008) supports the notion that service quality as perceived by customers, stems from a comparison of what they feel that service organisations should offer (i.e., from their expectations) with their perceptions of the performance of organisations providing the service. Customers' perceptions depend on their comparison of their prior quality and productivity depends not only on the performance of the service provider's personnel, but also on the performance of the customer. This gap between the customer's expectation of the quality of the service and the perceived quality of the service received can be explained by the Gaps Model. The Model proposes that expectations of customers are a function of disconfirmation and that a customer makes a comparison between his/her experience with pre-consumption expectations (before-service consumption) and post-consumption experience (after-service consumption). Based on this comparison, a state of satisfaction or dissatisfaction toward specific services is surmised.

\subsection{The Gaps Model}

Zeithaml et al. (2006) say that customer expectations are standards or reference points that customers bring into the service experience, whereas customer perceptions are subjective assessments of actual service experiences. The Gap Model draws a comparison between the qualities of a service that a customer expects to receive with the actual level of perceived service performance. The distinction between the disconfirmation paradigm, as it is called in customer satisfaction literature and the Gap Model in the service quality literature, has been highlighted in Iacobucci et al. (1995). The Gap Model identifies five gaps where there may be a shortfall between expectation of service levels and perception of actual service delivery (Koni et al., 2013). Figure 1 illustrates the Gap Model of service quality.

Customer expectations need to be properly understood to successfully manage them and service gaps should be identified from a customer's perspective (Miremadi et al., 2011).

The five gaps of service quality shown in Figure 1 are briefly enunciated as follows:

- $\quad$ Gap 1 is the difference between the actual expectation of customers and what the service marketer perceived as expectation of customers.

- Gap 2 is the difference between marketer perception of customer expectations and the translation of those perceptions into service quality specifications.

- $\quad$ Gap 3 is the difference between the customer service quality specifications and the actual service delivered by the marketer.

- $\quad$ Gap 4 is the difference between the actual service delivery and what is communicated to the customer.

- $\quad$ Gap 5 is the difference between the customer's perceived service and expected service. 


\section{CONSUMER}

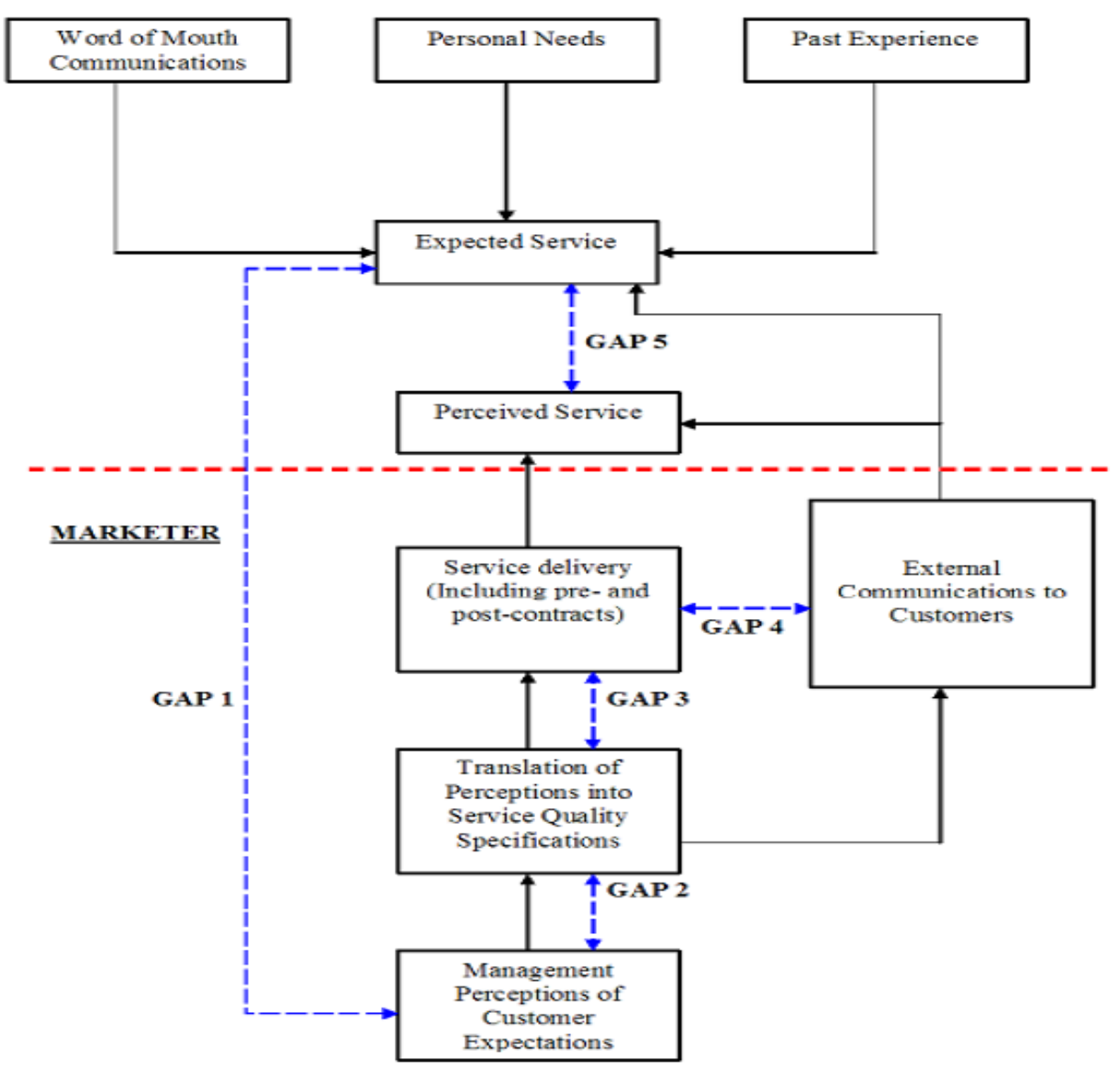

Source: Parasuraman, Zeithaml and Berry (1985: 44)

Figure 1: GAPs Model of Service Quality

The immediate focus of this study is to evaluate Gap 5 service quality in a higher education context. Gap 5 is the discrepancy between the customer's actual expectations for service quality and their perceptions of the actual service delivery. This gap forms the basis of a customer-oriented definition of service quality, but other gaps are contributors to the service quality gap that may be perceived by customers (Nitecki \& Hernon, 2000).

Parasuraman et al. (1988) originally proposed ten dimensions of service quality with five basic gaps to be analysed - tangibility, reliability, responsiveness, competence, courtesy, credibility, security, access, communication, and understanding the consumer. Their research was later refined leading to the development of the SERVQUAL scale which measures customers' perceptions of service quality. The original ten dimensions were later condensed into five:

- $\quad$ Tangibles: Appearance of physical facilities, equipment, personnel, and communication materials

- Reliability: Ability to dependably and accurately perform the promised service

- $\quad$ Responsiveness: Willingness to help customers and provide prompt service

- $\quad$ Assurance: Knowledge and courtesy of employees and their ability to convey trust \& confidence

- Empathy: Caring, individualized attention that the firm provides its customers

\section{RESEARCH METHODOLOGY}

This study aims to measure students' and staff's expectations and perceptions of service quality to determine their satisfaction in a higher education institution. The survey is the method of data collection and 
interpretation. The study used a sample of 280 respondents from a University in South Africa to obtain the score for each of the 26 expectation items.

\subsection{Respondents}

The data for this research was elicited by a survey that was administered to undergraduate students, as well as staff, between the ages of 17 and 60 years. These respondents were selected from Durban University of Technology in South Africa (researcher's university) for at least four consecutive semesters. The experience in a university is a fundamental requirement to measure service quality. The researcher received assistance from lecturers to administer the survey to second and third-year students of the University. Twenty minutes of the lecture time was used to complete the survey under a controlled environment. Surveys were administered to staff during the tea interval (between 10:00 and 10:20).

A convenience sampling technique was used to administer the survey across the two campuses. A total of 300 surveys were distributed to students and staff, of which 280 were returned as useful samples. The analysis of data reflects that the majority of the respondents (64.64\%) came from the Riverside campus. There were slight variations in the percentage of respondents from second-year $(39.29 \%)$ versus third-year $(37.50 \%)$ students and Academic (12.50) versus Administration staff (10.71). Most of the respondents that participated in this survey were in the age group of 17 to 21 years $(36.07 \%)$ and there were fewer males $(40.71 \%)$ than females $(59.29 \%)$. This reflects the population dominance of women over men in South Africa. Table 1 highlights the respondents profile.

Table 1: Respondents Profile

\begin{tabular}{|l|c|c|}
\hline \multicolumn{1}{|c|}{ Distribution } & Frequency (N) & Percentage (N\%) \\
\hline Campus & 181 & 64.64 \\
\hline Riverside & 99 & 35.36 \\
\hline Indumiso & 110 & 39.29 \\
\hline Year of Study & 105 & 37.50 \\
\hline $2^{\text {nd }}$ year & & 12.50 \\
\hline $3^{\text {rd }}$ year & 35 & 10.71 \\
\hline Type of Staff & 30 & 36.07 \\
\hline Academic & & 32.14 \\
\hline Administration & 101 & 09.43 \\
\hline Age & 90 & 07.86 \\
\hline $17-21$ years & 27 & 14.28 \\
\hline $22-26$ years & 22 & \\
\hline $27-31$ years & 40 & \\
\hline $32-36$ years & & \\
\hline Above 36 years & 114 & \\
\hline Gender & 166 & \\
\hline Male & & \\
\hline Female & & \\
\hline
\end{tabular}

\subsection{Instrument and Measurement}

The SERVQUAL survey comprised of two sections; i.e., customer service expectations of university services and customer service perceptions of the service received from the university. In the service expectations section, respondents were asked to indicate, on a seven-point Likert scale $(1=$ strongly disagree, $2=$ disagree, $3=$ mildly disagree, $4=$ neutral, $5=$ mildly agree, $6=$ agree and $7=$ strongly agree), the extent to which they believe an ideal university possesses the characteristics described in the statements. The perceptions section required respondents to indicate the extent to which the university possesses the characteristics described in the statements. The survey was divided into five dimensions:

- Dimension 1: Physical and Academic Services - the physical facilities and the ability to reliably and accurately perform the promised service. These statements (1-10) encompass attributes of Tangibles and Reliability (Parasuraman, 2004, p. 46). 
- $\quad$ Dimension 2: Commitment to Serve - the willingness to help the customer and provide prompt service. These statements $(1-5)$ encompass the attributes of Responsiveness (Parasuraman, 2004, p. 46).

- Dimension 3: Human Factors - the provision of caring, individual attention to customers. These statements (1 - 4) encompass the attributes of Empathy (Parasuraman, 2004, p. 46).

- Dimension 4: Visual Aspects - the appearance of equipment, personnel and communication materials. These statements $(1-4)$ encompass the attributes of Tangibles (Parasuraman, 2004, p. 46).

- $\quad$ Dimension 5: General Attitudes - the knowledge and courtesy of employees and their ability to convey trust and confidence. These statements $(1-3)$ encompass the attributes of Assurance (Parasuraman, 2004, p. 46).

\subsection{Data Analysis}

The SERVQUAL survey was used to measure service quality and the assessment involved computing the difference between the ratings assigned to the expectations and perceptions statements; i.e., $\mathrm{SQ}=\mathrm{P}-\mathrm{E}$. (Youseff et al., 1995). An average score was calculated for each response on the statements in both the expectation and perception section of the SERVQUAL survey based on the seven-point Likert scale. The statistical tests were administered on IBM SPSS version 20.0, as the statistics on SPSS are equipped to handle empirical data. The MannWhitney statistical test was used to draw comparisons and to identify any significant differences. This test is used extensively for comparing the differences between two independent samples which, in the case of this study, is Riverside Staff versus Indumiso Staff; Riverside staff versus Indumiso students, and Indumiso staff versus Riverside students.

\subsection{Reliability}

To determine the reliability of the data collected, Cronbach's Alpha was calculated. Cronbach Alpha ranges between 0 and 1, with 0 indicating a perfectly unreliable measurement and 1 being a perfectly reliable measurement. The Cronbach Alpha was calculated for each subscale or service quality dimension in the survey (results are tabulated in Table 2).

Table 2: Cronbach Alpha Test for Reliability

\begin{tabular}{|c|c|c|c|c|}
\hline & Service Quality Dimensions & Number Of Respondents & $\begin{array}{c}\text { Expectation } \\
\text { Cronbach's Alpha }\end{array}$ & $\begin{array}{c}\text { Perception } \\
\text { Cronbach's Alpha }\end{array}$ \\
\hline 1 & Physical \& Academic Services & 280 & 0.844 & 0.878 \\
\hline 2 & Commitment to Serve & 280 & 0.787 & 0.899 \\
\hline 3 & Human Factor & 280 & 0.832 & 0.856 \\
\hline 4 & Visual Aspect & 280 & 0.766 & 0.790 \\
\hline 5 & General Attitudes & 280 & 0.757 & 0.808 \\
\hline
\end{tabular}

All Cronbach's Alpha coefficients are higher than 0.7 , indicating a reasonably high level of reliability of the measurement instrument; i.e., the questionnaire.

\section{FINDINGS AND ANALYSIS}

Table 3 shows the factor score for each of the five dimensions as well as the factor score for each statement from the five dimensions. The scores indicate that expectations have all exceeded the perceptions by roughly 1 or 2 units. The biggest differences are with regard to physical and academic services (-2.208), commitment to serve $(-.020)$, and visual aspects (-2.063). 
Table 3: Overall Dimension Scores

\begin{tabular}{|c|c|c|c|c|c|}
\hline & Statement & Perceptions & Expectations & Difference/Factor Score & Factor Score \\
\hline & & Mean & Mean & & \\
\hline \multirow{10}{*}{ Dimension 1} & 1 & 3.25 & 6.26 & -3.01 & \\
\hline & 2 & 3.19 & 6.34 & -3.15 & \\
\hline & 3 & 4.94 & 6.32 & -1.38 & \\
\hline & 4 & 3.67 & 6.21 & -2.54 & \\
\hline & 5 & 4.71 & 6.2 & -1.49 & \\
\hline & 6 & 3.73 & 5.91 & -2.18 & \\
\hline & 7 & 3.35 & 6.12 & -2.77 & \\
\hline & 8 & 3.62 & 5.63 & -2.01 & \\
\hline & 9 & 3.96 & 6.17 & -2.21 & \\
\hline & 10 & 5.28 & 6.62 & -1.34 & -2.208 \\
\hline \multirow{5}{*}{ Dimension 2} & 1 & 4.03 & 6.13 & -2.1 & \\
\hline & 2 & 3.95 & 6.2 & -2.25 & \\
\hline & 3 & 4.35 & 6.17 & -1.82 & \\
\hline & 4 & 3.88 & 5.89 & -2.01 & \\
\hline & 5 & 3.81 & 5.73 & -1.92 & -2.020 \\
\hline \multirow[t]{4}{*}{ Dimension 3} & 1 & 4.28 & 6.07 & -1.79 & \\
\hline & 2 & 4.15 & 6.48 & -2.33 & \\
\hline & 3 & 4.36 & 6.05 & -1.69 & \\
\hline & 4 & 4.4 & 6.01 & -1.61 & -1.855 \\
\hline \multirow{4}{*}{ Dimension 4} & 1 & 3.12 & 6.04 & -2.92 & \\
\hline & 2 & 3.27 & 5.89 & -2.62 & \\
\hline & 3 & 4.97 & 6.05 & -1.08 & \\
\hline & 4 & 4.41 & 6.04 & -1.63 & -2.0625 \\
\hline \multirow[t]{3}{*}{ Dimension 5} & 1 & 4.46 & 6.31 & -1.85 & \\
\hline & 2 & 4.86 & 6.29 & -1.43 & \\
\hline & 3 & 4.62 & 6.23 & -1.61 & -1.630 \\
\hline
\end{tabular}

Graphically, the SERVQUAL index is therefore as shown in Figure 2 and Table 4.

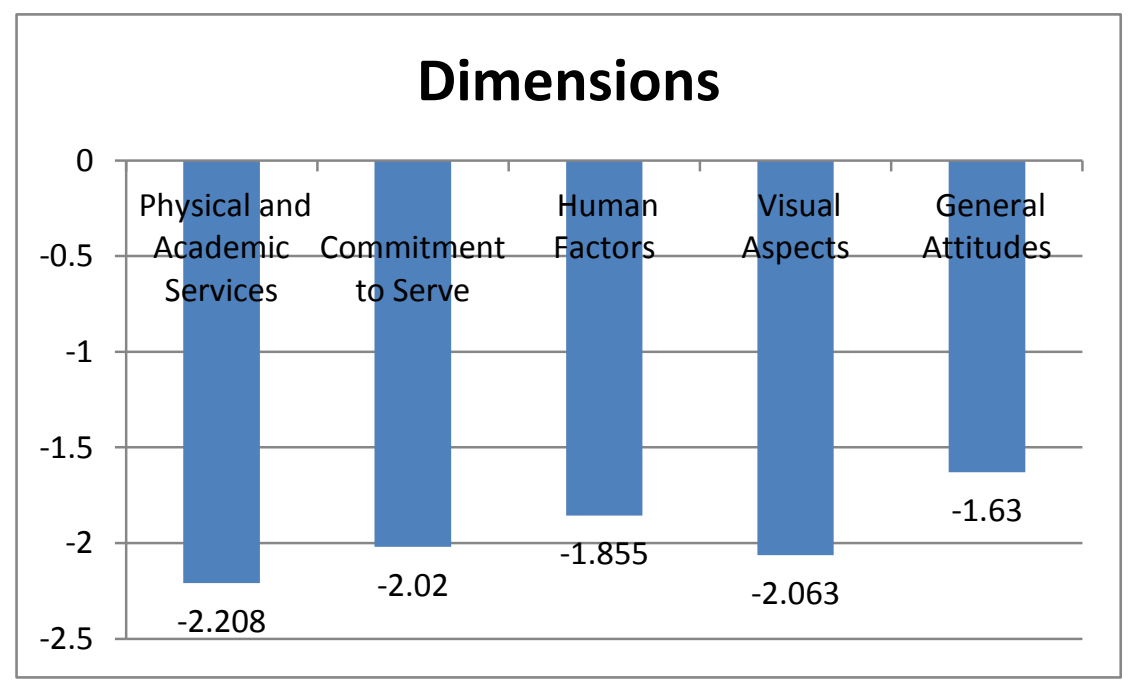

Figure 2: SERVQUAL Index per Dimension 
Table 4: Overall SERVQUAL Index

\begin{tabular}{|l|l|}
\hline \multicolumn{1}{|c|}{ Dimensions } & \multicolumn{1}{|c|}{ Score } \\
\hline Physical and Academic Services & -2.208 \\
\hline Commitment to Serve & -2.020 \\
\hline Human Factors & -1.855 \\
\hline Visual Aspects & -2.063 \\
\hline General Attitudes & -1.630 \\
\hline Overall SERVQUAL & $\mathbf{- 1 . 9 5 5}$ \\
\hline
\end{tabular}

The Gap analysis clearly indicates that there is a significant difference between expectations and perceptions of the respondents. The substantially large number of gaps, which is evident across all dimensions, is indicative of a considerable discrepancy between the expectations and perceptions of the respondents. Following is an analytical discussion of each of the five dimensions.

\subsection{Analysis of the Physical and Academic Services Gap}

This was the highest recorded gap of the five dimensions. The overall average gap score for the dimension physical and academic services was -2.208 . The biggest contributor (-3.15) to this difference between expectations and perceptions in this dimension was the statement that excellent universities need to have modern libraries with complete collections. Another key contributor to this gap was the statement that excellent universities have complete and modern laboratories (-3.01). This indicates that the DUT needs to provide complete and modern laboratories if the institution wants to gain a competitive advantage.

\subsection{Analysis of the Commitment to Serve Gap}

This dimension was the third highest recorded gap. The overall average gap score for commitment to serve was found to be (-2.02). This implies that customers of the DUT are not completely satisfied with the commitment to serve aspect of service quality. The biggest contributor $(-2.25)$ to this difference between expectations and perceptions in this factor was the statement that excellent universities provide quick and prompt service. This indicates that the customers of the DUT are not happy with this quality of service and the DUT must put measures in place to counteract this problem.

The second biggest contributor (-2.10) to this difference in this dimension was the statement that excellent universities show interest in solving students' problems. The students indicated that they are not satisfied with the type of service they are receiving from staff showing interest in solving student queries and concerns. It is important for the management of the DUT to address this issue as students are one of the most important stakeholders to the institution.

\subsection{Analysis of the Human Factor Gap}

The overall gap score for the human factor was found to be (-1.85). This was the second lowest recorded gap score of the five dimensions. The highest statement gap score for this dimension of service quality was $(-2.33)$ which was for the statement that excellent universities provide accurate and timely information.

The second biggest contributor (-1.79) to this difference between expectations and perceptions in this dimension was the statement that excellent universities apply discipline to everybody. This would indicate that customers of the DUT do not feel that the discipline instituted by the DUT is executed fairly.

\subsection{Analysis of the Visual Aspect Gap}

The overall gap score for visual aspects was found to be (2.0625). This was the second highest recorded gap score of the five dimensions. The biggest contributor $(-2.92)$ to this gap was the statement of excellent universities have modern-looking equipment. This implies that the management of the DUT needs to address the issue of having modern-looking equipment. This is particularly an important issue to rectify at a university of 
technology, as du Pré (2009) states that a University of Technology (UOT) is different from any other university in that a UOT focuses on the study of technology from the viewpoint of various fields of study and involves the interweaving, interrelation between technology, and nature of the university.

The second biggest overall contributor (-2.62) in this dimension was the statement physical facilities of an excellent university are visually appealing. This indicates that the customers of the DUT do not find the physical facilities of the institution visually appealing. Management can rectify this by ensuring that changes are made to ensure that the physical facilities are made visually appealing.

\subsection{Analysis of the General Attitudes Gap}

The overall average gap score for general attitudes was found to be (-1.63). This was the lowest recorded gap score of the five dimensions. The highest statement gap score for this dimension was (-1.85) for the statement excellent universities have good admission procedures to recruit qualified students. This implies that the DUT does not have good admission procedures to recruit qualified students. Management can ensure that policies and procedures are designed and implemented in order to rectify this issue of service quality.

The following discussion is a comparison of perception scores between staff versus staff; Riverside staff versus Indumiso students, and Indumiso staff versus Riverside students.

\subsection{Comparison of Staff versus Staff on Each Campus}

The Mann-Whitney Test was used to compare staff versus staff on each campus with respect to their perceptions; results are shown in Table 5.

Table 5: Significance of Indumiso versus Riverside Staff Regarding Perception Scores

\begin{tabular}{|c|c|c|c|c|}
\hline & $\begin{array}{c}\text { Mann- } \\
\text { Whitney U }\end{array}$ & $\begin{array}{l}\text { Wilcoxon } \\
\text { W }\end{array}$ & $\mathbf{Z}$ & $\begin{array}{l}\text { Asymp. Sig. } \\
\text { (2-tailed) }\end{array}$ \\
\hline DUT has complete and modern laboratories & 282.000 & 877.000 & -1.067 & .286 \\
\hline DUT has modern library with complete collection & 253.500 & 848.500 & -1.586 & .113 \\
\hline DUT provides students with health care & 257.500 & 467.500 & -1.527 & .127 \\
\hline DUT has a pleasant campus environment & 245.500 & 840.500 & -1.726 & .084 \\
\hline DUT provides practical and applied oriented courses & 305.000 & 900.000 & -.651 & .515 \\
\hline DUT performs the service right the first time & 180.500 & 775.500 & -2.932 & .003 \\
\hline DUT provides their service at the time they promise to do so & 255.000 & 850.000 & -1.552 & .121 \\
\hline Administrative services at DUT provide error-free records & 289.000 & 884.000 & -.931 & .352 \\
\hline $\begin{array}{l}\text { Employees of DUT tell students exactly when services will be } \\
\text { performed }\end{array}$ & 306.500 & 901.500 & -.614 & .540 \\
\hline DUT has qualified lecturers & 274.000 & 484.000 & -1.232 & .218 \\
\hline DUT shows interest in solving students' problems & 224.500 & 819.500 & -2.109 & .035 \\
\hline Employees of DUT provide quick and prompt service & 276.000 & 871.000 & -1.170 & .242 \\
\hline Employees of DUT are ready to help & 292.000 & 887.000 & -.877 & .381 \\
\hline Employees of DUT are never too busy to respond to requests & 274.500 & 869.500 & -1.201 & .230 \\
\hline DUT gives individuals attention & 275.500 & 870.500 & -1.184 & .236 \\
\hline DUT applies discipline to everybody & 216.000 & 811.000 & -2.257 & .024 \\
\hline DUT provides accurate and timely information & 259.500 & 854.500 & -1.462 & .144 \\
\hline DUT creates harmonious relationships among staff and students & 241.500 & 836.500 & -1.795 & .073 \\
\hline DUT develops democratic campus regulations & 283.500 & 878.500 & -1.032 & .302 \\
\hline DUT has modern-looking equipment & 215.000 & 810.000 & -2.290 & .022 \\
\hline The physical facilities of DUT are visually appealing & 181.500 & 776.500 & -2.892 & .004 \\
\hline Employees at DUT are neat-appearing & 322.000 & 917.000 & -.330 & .741 \\
\hline $\begin{array}{l}\text { Materials associated with the service (such as pamphlets or } \\
\text { statements) of DUT are visually appealing }\end{array}$ & 319.500 & 914.500 & -.379 & .705 \\
\hline DUT has good admission-procedure to recruit qualified students & 240.000 & 835.000 & -1.825 & .068 \\
\hline $\begin{array}{l}\text { Lecturers of DUT assess and evaluate students' achievement } \\
\text { objectively }\end{array}$ & 261.000 & 856.000 & -1.467 & .142 \\
\hline Employees of DUT treat students courteously & 272.000 & 867.000 & -1.245 & .213 \\
\hline
\end{tabular}


$\mathbf{H}_{\mathbf{0}}$ : $\quad$ There are no differences between the Indumiso staff and Riverside staff with respect to their perceptions.

$\mathbf{H}_{1}$ : There are differences between the Indumiso staff and Riversides staff with respect to their perceptions.

At the 5\% significance level, $\mathrm{H}_{\mathrm{o}}$ will be rejected for all the p-values less than 0.05 (the shaded ones) and it will be concluded that there are differences between the Indumiso staff and Riverside staff with respect to their perceptions. Otherwise, for the (unshaded questions), $\mathrm{H}_{0}$ will be accepted.

\subsection{Comparison of Staff versus Students}

The Mann-Whitney Test was used to compare staff versus students on each campus with respect to their expectations; results are shown in Table 6.

Table 6: Significance of Indumiso Students versus Riverside Staff Regarding Expectation Scores

\begin{tabular}{|c|c|c|c|c|}
\hline & $\begin{array}{c}\text { Mann- } \\
\text { Whitney U }\end{array}$ & $\begin{array}{l}\text { Wilcoxon } \\
\text { W }\end{array}$ & $\mathbf{Z}$ & $\begin{array}{l}\text { Asymp. Sig. } \\
\text { (2-tailed) }\end{array}$ \\
\hline An excellent university has complete and modern laboratories & 3443.500 & 6603.500 & -5.185 & .000 \\
\hline An excellent university has modern library with complete collection & 4160.500 & 7320.500 & -3.600 & .000 \\
\hline An excellent university provides students with health care & 3683.500 & 6843.500 & -4.614 & .000 \\
\hline An excellent university has a pleasant campus environment & 3617.500 & 6777.500 & -4.731 & .000 \\
\hline $\begin{array}{l}\text { An excellent university provides practical and applied oriented } \\
\text { courses }\end{array}$ & 4592.000 & 7752.000 & -2.631 & .009 \\
\hline An excellent university performs the service right the first time & 3979.500 & 7139.500 & -3.948 & .000 \\
\hline $\begin{array}{l}\text { An excellent university provides their service at the time they promise } \\
\text { to do so }\end{array}$ & 4027.000 & 7187.000 & -3.884 & .000 \\
\hline $\begin{array}{l}\text { Administrative services of an excellent university will provide error- } \\
\text { free records }\end{array}$ & 3907.000 & 7067.000 & -4.118 & .000 \\
\hline $\begin{array}{l}\text { Employees of an excellent university will tell students exactly when } \\
\text { services will be performed }\end{array}$ & 3374.000 & 6534.000 & -5.257 & .000 \\
\hline An excellent university has qualified lecturers & 2753.500 & 5913.500 & -6.734 & .000 \\
\hline An excellent university shows interest in solving students' problems & 3391.000 & 6551.000 & -5.220 & .000 \\
\hline $\begin{array}{l}\text { Employees of an excellent university provide quick and prompt } \\
\text { service }\end{array}$ & 3588.500 & 6748.500 & -4.788 & .000 \\
\hline Employees of an excellent university are ready to help & 3246.000 & 6406.000 & -5.530 & .000 \\
\hline $\begin{array}{l}\text { Employees of an excellent university are never too busy to respond to } \\
\text { requests }\end{array}$ & 3772.000 & 6932.000 & -4.394 & .000 \\
\hline An excellent university gives individuals attention & 3526.500 & 6686.500 & -4.944 & .000 \\
\hline An excellent university applies discipline to everybody & 3944.500 & 7104.500 & -4.025 & .000 \\
\hline Excellent universities provide accurate and timely information & 3712.500 & 6872.500 & -4.527 & .000 \\
\hline $\begin{array}{l}\text { Excellent universities create harmonious relationships among staff and } \\
\text { students }\end{array}$ & 4151.500 & 7311.500 & -3.578 & .000 \\
\hline An excellent university develops democratic campus regulations & 4358.000 & 7518.000 & -3.138 & .002 \\
\hline An excellent university has modern-looking equipment & 3964.500 & 7124.500 & -4.033 & .000 \\
\hline The physical facilities of an excellent university are visually appealing & 3857.000 & 7017.000 & -4.231 & .000 \\
\hline Employees at an excellent university are neat-appearing & 4614.000 & 7774.000 & -2.594 & .009 \\
\hline $\begin{array}{l}\text { Materials associated with the service (such as pamphlets or } \\
\text { statements) of an excellent university will be visually appealing }\end{array}$ & 4083.000 & 7243.000 & -3.724 & .000 \\
\hline $\begin{array}{l}\text { Excellent universities have good admission-procedure to recruit } \\
\text { qualified students }\end{array}$ & 4344.500 & 7504.500 & -3.168 & .002 \\
\hline $\begin{array}{l}\text { Lecturers of excellent universities assess and evaluate students' } \\
\text { achievement objectively }\end{array}$ & 3976.000 & 7136.000 & -3.970 & .000 \\
\hline Employees of an excellent university treat students courteously & 3507.000 & 6667.000 & -4.981 & .000 \\
\hline
\end{tabular}

\subsubsection{Mann Whitney Test}

$\mathbf{H}_{0}$ : There are no differences between the Indumiso students and Riverside staff with respect to their perceptions.

$\mathbf{H}_{1}$ : There are differences between the Indumiso students and Riverside staff with respect to their perceptions. 
At the 5\% significance level, $\mathrm{H}_{\mathrm{o}}$ will be rejected for all the p-values less than 0.05 (the shaded ones) and it will be concluded that there are differences between the Indumiso staff and Riverside students with respect to their expectations.

\subsection{Comparison of Indumiso Staff versus Riverside Students}

The Mann-Whitney Test was used to compare Indumiso staff versus Riverside students on each campus with respect to their expectations; results are shown in Table 7.

Table 7: Significance of Indumiso Students versus Riverside Staff Regarding Expectation Scores

\begin{tabular}{|c|c|c|c|c|}
\hline & $\begin{array}{c}\text { Mann- } \\
\text { Whitney U }\end{array}$ & $\begin{array}{c}\text { Wilcoxon } \\
\text { W } \\
\end{array}$ & $\mathbf{Z}$ & $\begin{array}{c}\text { Asymp. Sig. } \\
\text { (2-tailed) }\end{array}$ \\
\hline An excellent university has complete and modern laboratories & 4533.000 & 15411.000 & -3.277 & .001 \\
\hline An excellent university has modern library with complete collection & 4125.000 & 15003.000 & -4.213 & .000 \\
\hline An excellent university provides students with health care & 4521.000 & 15252.000 & -3.153 & .002 \\
\hline An excellent university has a pleasant campus environment & 4660.000 & 15538.000 & -2.722 & .006 \\
\hline $\begin{array}{l}\text { An excellent university provides practical and applied oriented } \\
\text { courses }\end{array}$ & 4312.000 & 15190.000 & -3.477 & .001 \\
\hline An excellent university performs the service right the first time & 4308.500 & 15186.500 & -3.408 & .001 \\
\hline $\begin{array}{l}\text { An excellent university provides their service at the time they promise } \\
\text { to do so }\end{array}$ & 4557.000 & 15435.000 & -2.950 & .003 \\
\hline $\begin{array}{l}\text { Administrative services of an excellent university will provide error- } \\
\text { free records }\end{array}$ & 4991.000 & 15869.000 & -1.808 & .071 \\
\hline $\begin{array}{l}\text { Employees of an excellent university will tell students exactly when } \\
\text { services will be performed }\end{array}$ & 5394.500 & 16272.500 & -.979 & .328 \\
\hline An excellent university has qualified lecturers & 5653.000 & 16531.000 & -.470 & .638 \\
\hline An excellent university shows interest in solving students' problems & 4550.000 & 15428.000 & -2.955 & .003 \\
\hline $\begin{array}{l}\text { Employees of an excellent university provide quick and prompt } \\
\text { service }\end{array}$ & 4465.500 & 15343.500 & -3.120 & .002 \\
\hline Employees of an excellent university are ready to help & 5660.000 & 16538.000 & -.344 & .731 \\
\hline $\begin{array}{l}\text { Employees of an excellent university are never too busy to respond to } \\
\text { requests }\end{array}$ & 5736.000 & 16614.000 & -.161 & .872 \\
\hline An excellent university gives individuals attention & 5624.000 & 16502.000 & -.412 & .681 \\
\hline An excellent university applies discipline to everybody & 5508.500 & 16386.500 & -.694 & .488 \\
\hline Excellent universities provide accurate and timely information & 5074.500 & 15952.500 & -1.751 & .080 \\
\hline $\begin{array}{l}\text { Excellent universities create harmonious relationships among staff } \\
\text { and students }\end{array}$ & 5441.000 & 16319.000 & -.835 & .404 \\
\hline An excellent university develops democratic campus regulations & 5510.000 & 16388.000 & -.683 & .495 \\
\hline An excellent university has modern-looking equipment & 4892.000 & 15770.000 & -2.169 & .030 \\
\hline $\begin{array}{l}\text { The physical facilities of an excellent university are visually } \\
\text { appealing }\end{array}$ & 4698.000 & 15576.000 & -2.501 & .012 \\
\hline Employees at an excellent university are neat-appearing & 5122.000 & 16000.000 & -1.591 & .112 \\
\hline $\begin{array}{l}\text { Materials associated with the service (such as pamphlets or } \\
\text { statements) of an excellent university will be visually appealing }\end{array}$ & 5732.500 & 16610.500 & -.170 & .865 \\
\hline $\begin{array}{l}\text { Excellent universities have good admission-procedure to recruit } \\
\text { qualified students }\end{array}$ & 5440.000 & 16318.000 & -.882 & .378 \\
\hline $\begin{array}{l}\text { Lecturers of excellent universities assess and evaluate students' } \\
\text { achievement objectively }\end{array}$ & 4572.000 & 15450.000 & -2.946 & .003 \\
\hline Employees of an excellent university treat students courteously & 5283.000 & 16161.000 & -1.240 & .215 \\
\hline
\end{tabular}

$\mathbf{H}_{0}$ : There are no differences between the Indumiso staff and Riverside students with respect to their expectations.

$\mathbf{H}_{1}$ : $\quad$ There are differences between the Indumiso staff and Riverside students with respect to their expectations.

At the 5\% significance level, $\mathrm{H}_{\mathrm{o}}$ will be rejected for all the p-values less than 0.05 (the shaded ones) and it will be concluded that there are differences between the Indumiso staff and Riverside students with respect to their expectations. Otherwise, for the (unshaded questions), $\mathrm{H}_{0}$ will be accepted. 
The above test results show that there are differences in expectations of services among staff and students on both the Riverside and Indumiso Campuses of the Durban University of Technology.

\section{CONCLUSION}

This study has measured the expectations and perceptions of students and staff in order to gauge the service quality in a higher education institution. All five dimensions - physical and academic services, commitment to serve, human factors, visual factors, and general attitude - revealed that both students and staff are dissatisfied with the service quality received at the DUT. The findings reveal that, on average, customers had high expectations in tangibles, reliability and assurance dimensions and their highest perceptions were found in the assurance dimension. The study opens the door to conduct similar studies across other public and private universities and to establish comparison of the results. Additionally, the results of this study have started efforts to measure and compare student satisfaction regarding services provided at other universities in South Africa. Replication studies using large samples would be useful in order to corroborate this study's findings and to address the limitation of the study for a single case study.

\section{ACKNOWLEDGEMENTS}

This work is based on the research supported, in part, by the National Research Foundation of South Africa Unique Grant No. 86437.

\section{AUTHOR INFORMATION}

Dr. Paul Green is a Senior Lecturer in the Department of Finance \& Information Management at the Durban University of Technology. His research interests include Systems Thinking, Evaluation, Service Quality and Universities of Technology. He has published in peer-reviewed journals and presented numerous papers at international conferences. E-mail: paulg@dut.ac.za

\section{REFERENCES}

1. Abu Hasan, H., Ilias, R., Rahman, R., \& Abd Razak, M. (2008). Service quality and student satisfaction: A case study at private higher education institutions. International Business Research, 1(3), 136-175.

2. Bolton, R. N., \& Drew, J. H. (1991). A longitudinal analysis of the impact of services changes on customer attitudes. Journal of Marketing, 55, 1-9.

3. Cronin, J. J., \& Taylor, S. A. (1992). Measuring service quality: A re-examination and extension. Journal of Marketing, 56, 55-68.

4. Cuthbert, P. F. (1996). Managing service quality in HE: Is SERVQUAL the answer? Part 1. Managing Service Quality, 6(2), 11-16.

5. du Pré, R. (2009). The place and role of universities of technology in South Africa. Bloemfontein, South Africa: South African Technology Network.

6. Grönroos, C. (2008) Service logic revisited: Who creates value? And who co-creates? European Business Review, 20(4), 298-314.

7. Iacobucci, D., Ostrom A., \& Grayson, K. (1995). Distinguishing service quality and customer satisfaction. Journal of Consumer Psychology, 4(3), 277-303.

8. Jain, R., Sinha, G., \& De, S. K. (2010). Service quality in higher education: An exploratory study. Asian Journal of Marketing, 4(3), 144-154.

9. Jain, R., Sinha, G., \& Sahney, S. (2011). Conceptualizing service quality in higher education. Asian Journal on Quality, 12(3), 296-314.

10. Khodayari, F., \& Khodayari, B. (2011). Service quality in higher education. Interdisciplinary Journal of Research in Business, 1(9), 38-46.

11. Koni, A., Zainal, K., \& Ibrahim, M. (2013). An assessment of the services quality of Palestine higher education. International Education Studies, 6(2), 3-48.

12. Lee, J. (2010). Online support service quality, online learning acceptance and student satisfaction. Internet and Higher Education, 13, 277-283. 
13. Lewis, B. R., \& Mitchell, V. W. (1990). Defining and measuring the quality of customer service. Marketing Intelligence \& Planning, 8(6), 11-17.

14. Mahadzirah, M., \& Wan, N. M. (2003). A field of the influence of job satisfaction on customer focus in public higher learning institutions in Malaysia. Proceedings of Asian Pacific Economic Conference, 2003. (pp. 162-171).

15. Miremadi, A., Ghalamkari, S., \& Sadeh, F. (2011). Customer satisfaction in port industry (A case study of Iranian shipping). 2011 International Conference on Sociality and Economics Development, IPEDR IACSIT Press, Singapore. Vol. 10. (pp. 58-62).

16. Nitecki, D. A., \& Hernon, P. (2000). Measuring service quality at Yale University's libraries. The Journal of Academic Librarianship, 26(4), 259-273.

17. Palmer, A. (2001). Principles of service marketing ( $3^{\text {rd }}$ ed.). UK: McGraw Hill.

18. Parasuraman, A. (2004). Assessing and improving service performance for maximum impact: Insights from a two-decade-long research journey. Performance Measurements and Metrics, 5(2), 45-52.

19. Parasuraman, A., Zeithaml, V. A., \& Berry, L. L. (1985). A conceptual model service quality and its implications for future research. Journal of Marketing, 49(4), 41-50.

20. Peng, P., \& Samah, A. (2006). Measuring students' satisfaction for quality education in e-learning university. UNITAR E Journal, 2(1), 11-21.

21. Pereda, M., Airey, D., \& Bennett, M. (2007). Service quality in overseas education: The experience of overseas students. Journal of Hospitality, Leisure, Sport and Tourism Education, 6(2), 55-67.

22. Petruzzellis, L., D’Uggento, A., \& Romanazze, S. (2006). Student satisfaction and quality of service in Italian universities. Managing Service Quality, 16(4), 349-364.

23. Sultan, P., \& Wong, H. Y. (2012). Service quality in a higher education context: An integrated model. Asia Pacific Journal of Marketing and Logistics, 24(5), 755-784.

24. Youssef, F., Nel, D., \& Bovaird, T. (1995). Service quality in NHS hospitals. Journal of Management in Medicine, 9(1), 66-74.

25. Zeithaml, V. A., Bitner, M. J., \& Gremler, D. D. (2006). Services marketing. Integrating customer focus across the firm ( $4^{\text {th }}$ ed.). USA: McGraw-Hill/Irwin. 